\title{
sciendo
}

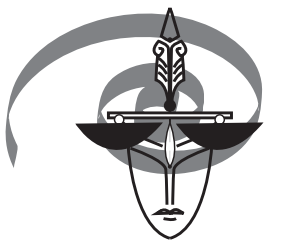

EUROPEAN

POLYGRAPH

Volume $13 \cdot 2019 \cdot$ Number $1(47)$

DOI: 10.2478/ep-2019-0001

Stanley M. Slowik*

Stanley M. Slowik, Inc., Evergreen, Colorado, United States

Frank S. Horvath** Michigan State University, Emeritus

United States

\section{Chicago: Where Polygraph Becomes a Science}

Чикаго: где полиграф становится наукой

Key words: History of polygraph, polygraph in Chicago, John E. Reid

\section{Abstract}

In the 1920's, earlier work on polygraph instrumentation and procedure in Europe and the United States came together in Chicago where John Reid and Fred Inbau at the Scientific Crime Laboratory applied extensive field observations in real life criminal cases to create the Comparison Question and semi-objective scoring technique, the factors that allowed polygraph to achieve scientific status.

While Chicago was not the first place the instrumental detection of deception was attempted, it was the place where the contemporary, comparison question technique was first developed and polygraph became a science. This fortuitous development was

\footnotetext{
*slowik@att.net

**horvathf@twc.com
} 
the result of the unlikely assemblage of a remarkable group of polygraph pioneers and a ready supply of criminal suspects.

It is impossible to pinpoint when people first began noticing the relationship between lying and observable changes in the body. The early Greeks founded the science of physiognomy in which they correlated facial expressions and physical gestures to impute various personality characteristics. The ancient Asians noted the connection between lying and saliva concluding that liars have a difficult time chewing and swallowing rice when being deceptive. Clearly, behavioral detection of deception pre-dates instrumental detection of deception which, it is equally clear, is European in origin. By 1858 Etienne-Jules Marey, the grandfather of cinematography recently feted in Martin Scorsese's film Hugo, and Claude Bernard, a French physiologist, described how emotions trigger involuntary physiological changes and created a "cardiograph" that recorded blood pressure and pulse changes to stimuli such as nausea and stress (Bunn, 2012). Cesare Lombroso, often credited as the founder of criminology, published the first of five editions of L'uomo delinquente in 1876 in which he postulated that criminals were degenerates or throwbacks to earlier forms of human development. Lombroso later modified his theory of "born criminals" by creating three heretical classes of criminals: habitual, insane and emotional or passionate (Lombroso, 1876).

By 1898, Hans Gross, the Austrian jurist credited with starting the field of criminalistics, rejected the notion of "born criminals" and postulated that each crime was a scientific problem that should be resolved by the best of scientific and technical investigative aides (Gross, 2014). In 1906, Carl Jung used a galvanometer and glove blood pressure apparatus with a word association test and concluded that the responses of suspected criminals and mental perverts were the same (Jung, 1907).

In order to appreciate the important polygraph contributions that occurred in Chicago, one needs to first consider what was happening at Harvard University and in Berkeley, California at the beginning of the 2oth Century.

\section{The Harvard School}

At Harvard University's Departments of Psychology and Physiology, William James, Walter Cannon, Hugo Münsterberg and his student, William Moulton Marston, all conducted significant work in psychological theory relevant to present day polygraph. William James was the first to define emotions as bodily changes, specifically, that such changes were responses to recognizing an exciting stimuli. This notion was later captured in the somewhat simplistic "Fear does not make us run from the bear - running 
from the bear makes us experience the emotion of fear" (James, 1894). James was successful in recruiting Hugo Münsterberg from Germany to Harvard though subsequently they often disagreed with each other's work. Münsterberg extended Jung's work with delayed answers and the word association test using Matthaos Hipp's chronoscope, an electromagnetic timer capable of measuring very brief time intervals. Münsterberg concluded that delayed answers were an indication of deception. Unfortunately, since numerous physical, visual and mental pre-conditions can also significantly affect response time and can easily be manipulated, time response techniques were rejected by Marston and others, at least with regard to investigative applications. Münsterberg is credited with being the Father of Industrial Psychology and promoted the use of psychology to shape consumer desire. He subscribed to James' theory of the human automaton, that people acted according to a predetermined set of coded instructions. Münsterberg also wrote that perception was heavily affected by individual memory and sensory differences in which in turn effect responses to stimuli (Münsterberg, 1907). This basic notion was to resurface in present day discussions of polygraph standardization. While many procedural aspects of polygraph technique most certainly can and have been standardized, attempts to carry this into all aspects of polygraph can lead to serious decision errors. While comparison questions, for example, should generally match the topic of the relevant questions it is even more important that they be individually developed with the subject and not merely pulled by rote from a rigid, limited pre-determined list (Reid \& Inbau, 1977).

Münsterberg also maintained that the " $3^{\text {rd }}$ Degree", i.e. using physical force to coerce confessions, was an ineffective technique, not because of any moral or legal sensibilities, but because it was ineffective at obtaining the truth. The term " 3 rd Degree" has been credited to a $19^{\text {th }}$ century NYPD Detective, Thomas Bryne, alleged to have beaten confessions from suspects and the term a play on his name (Alder, 2007). Münsterberg appeared to be far more interested in curing, not detecting lies and proposed replacing judges and juries with scientific Instrumentation to resolve criminal cases (Münsterberg, 1922). This idea continues to haunt the polygraph profession with numerous decisions against polygraph admissibility on the grounds that it "usurps the provenance of the jury".

Münsterberg's most illustrious student, William Moulton Marston, developed the Systolic Blood Pressure test as a Senior at Harvard, claiming 94\% - 96\% accuracy in detecting deception (Marston, 1917). About the same time, Marston demonstrated that "good liars", i.e. subjects who seemed to enjoy lying, could disprove Münsterberg's theory that late answers on the word association test indicated deception and could, in fact, obtain faster chronoscope times than truth tellers. Marston was known as the originator of audience testing wherein he would test subjects to determine their response 
to various movies and products. In 1930 he had published The Art of Sound Pictures explaining what was needed to create a gripping story, how various gestures were associated with different passions and how to make movies emotionally safe from censorship (Marston \& Pitkin, 1930). In 1931 Universal Pictures employed Leonarde Keeler in Chicago to test DePaul University undergraduates watching Boris Karloff in the movie Frankenstein and, based upon the test results removed scenes in which the Monster drowns a small girl and Dr. Frankenstein compares himself to God (Mechan, 1931).

In 1928 Marston wrote Emotions of Normal People espousing his theory that the primary drive of all people was to submit to a higher power. This later became the premise of his comic book series, Suprema - The Wonder Woman for which Marston wrote all the scripts (Bunn, 1997).

Marston is best known in legal circles for his attempt, in 1922, to introduce his Systolic Blood Pressure test in U.S. v. Frye in which Frye was found guilty of $2^{\text {nd }}$ degree murder (U.S. v. Frye, 1922). In declining to admit Marston's test, Judge McCoy opined that lie detection was not yet a matter of common knowledge and if the test was adopted, the jury system would have to be abandoned. Upon appeal, in 1923, the District of Columbia Court of Appeals ignored Judge McCoy's concerns and focused on when a scientific principle is no longer experimental but demonstrable, therein establishing, until Daubert in 1993, the Frye Rule in which a scientific test has to be "sufficiently established to have gained general acceptance in the particular field in which it belongs" (Frye v. U.S., 1923).

Walter Cannon, long term Chair of the Department of Physiology at Harvard Medical School, extended Claude Bernard's early work on homeostasis concluding that physiological centering does not happen by chance but is the result of organized, physiological self-government. With fellow physiologist Philip Bard he developed the Cannon-Bard theory explaining why people feel emotions first and then act upon them, contrary to William James' assertion that "running from the bear makes us experience the emotion of fear". In 1915 he coined the term "fight or fight" in his book Bodily Changes in Pain, Hunger, Fear and Rage: An Account of Recent Researches into the Functions of Emotional Excitement (Cannon, 1915). Cannon proposed that diverse stimuli can produce the same physical response and, by inference, that the same stimuli can produce diverse physical responses. Applying this to modern polygraph examinations, some polygraph subjects respond consistently in all three of the standard parameters (BP/pulse, respiration and EDA), others in two of the three, some in only one of the three with inconsistent responses in each parameter being fairly typical. The reverse - that different stimuli can evoke similar responses - is easily seen by comparing Known or Probable Lie responses to Comparison Questions with Countermeasure exercises such as solving math problems, visualizing exciting thoughts, 
using memory, being asked confusing or ambiguous questions, the use of shocking or provocative words, unreviewed or surprise questions or the use of Directed Answer procedures. While all of these can produce similarly appearing responses, clearly they do not qualify as appropriate Comparisons due to their vast differences in triggering mechanisms. In short, Differential Salience should start with a level playing field apples-to-apples - and not similarly appearing response patterns caused by salience to very different stimuli (Reid, 1977). Someone whose personal value set perceives lying as negative conduct with negative consequences will react (if they react at all) for salience very different than someone being told to provide a Directed Answer or mentally solve a math problem. Comparison Questions are not created just to see if a subject is capable of responding but to see if they respond for the same reasons as lying to the Relevant Questions. Cannon's research on homeostasis is therefore, just as important to polygraph response theory today as his more familiar fight or flight (or freeze) theory was to polygraph pioneers.

\section{The Californians}

While scientists at Harvard were developing some of the early explanations for the psychophysiological mechanisms of the instrumental detection of deception, August Vollmer, John Larson and Leonarde Keeler were busy with the more practical applications of the emerging science.

August Vollmer, credited with the evolution of police work from an Honorable Occupation to a true Profession, was himself a veteran of the Spanish - American War with a $6^{\text {th }}$ grade education. Nevertheless, he insisted that law enforcement be completely independent from politics, that candidates have the highest standards, preferably a college education, and was a vocal proponent of the scientific investigation of crime, including the instrumental detection of deception (Deakin, 1988). Vollmer was Chief of Police in Berkeley, California and hired newly minted $\mathrm{PhD}$, John Larson, as a police officer, assigning Larson to look into William Moulton Marston's Systolic Blood Pressure test. In 1923, Vollmer was persuaded to become Chief of the Los Angeles Police Department at a time when then Chief Louis Oaks and 10\% of the Departments patrol officers were active members of the Ku Klux Klan. Despite Vollmer's attempts to separate law enforcement from politics, his tenure lasted less than a year but was significant because of its influence on the career of Leonarde Keeler. August Vollmer originally was Charles Keeler's, Leonarde's father, mailman. After becoming Police Chief at Berkeley and assigning John Larson to research Marston's work, Chief Vollmer assigned high school student, later University of California at Berkeley college student, Leonarde Keeler, to assist. When Vollmer went to Los Angeles, Leonarde followed and came in contact 
with a number of people who actually made refinements to the polygraph instrumentation being used by Larson for which Keeler was later credited.

Vollmer was later to reunite with Larson and Keeler in Chicago, albeit by very different paths. Vollmer was influential to a significant number of other former Berkeley police officers including O. W. Wilson who eventually became Chief of the Chicago Police Department and who retained the polygraph services of John Reid in Chicago to resolve numerous, infamous allegations of police misconduct.

Paradoxically, Vollmer wasn't always the pinnacle of professionalism for which he is best known. He was known to complain about "by the book" requirements and "the foolish worship of technicalities" which undid arrests. Vollmer sometimes expressed a desire to see his officers "shoot a few criminals to set an example", the antithesis of modern law enforcement philosophy (Los Angeles Times, 1924). There is no evidence that Vollmer ever did any of the foregoing other than saying things for dramatic effect. In fact, Vollmer is often cited for his expressed desire to use police for prevention, not punishment.

John Larson of Nova Scotia received his Masters from Boston University with a thesis describing a method for fingerprint identification, though his methodology was never adopted. He received his Doctorate in Physiology from the University of California and was hired by Chief August Vollmer at the Berkeley Police Department becoming the very first "Police $\mathrm{PhD}$ ", but only one of Vollmer's many "College Cops". It was somewhat unsettling to hear that as recently as 2015 the American Polygraph Association was actually considering making exceptions to the original 1966 college degree membership requirement that Vollmer felt necessary for basic police work in 1918. Vollmer assigned Larson to expand upon Marston's earlier work at Harvard and shortly thereafter Larson developed a method to continuously record blood pressure/pulse, a significant advancement over Marston's periodic recordings. Notably, nearly all of Larson's work involved actual criminal suspects. Some of his earliest reported cases involved Sorority members suspected of dorm room thefts, polygraph subjects who were actual suspects, not college students participating in simulated laboratory studies. When times were slow at the Police Department, Larson would sometimes have his fellow officers round-up hobos and give them Searching Peaks polygraph examinations using maps to find out where, in the United States, they were from and whether they were, in fact, WWI Army deserters. Larson corroborated his polygraph charts with confessions but then did something extraordinary. He conducted "clearing charts" and noted that post-confession charts were very similar to innocent subject charts, a practice, with the notable exception of some intelligence cases, seldom practiced today. Larson was also the first to describe the problem of false positives in polygraph examinations theorizing that innocent subjects give deceptive responses to the Relevant Questions over the Ir- 
relevant Questions due to guilt and shame rather than deception (Detroit News, 1948; Redstone, 1947).

It is difficult to identify the person responsible for creating the original Relevant/Irrelevant polygraph technique. Clearly Marston used a version of the technique prior to Frye's 1922 Systolic Blood Pressure test. Larson, who was aware of Marston's work, appears to be using a similar technique, as well as a searching Peak of Tension test. However, it is not clear, when one considers Jung's and Munsterberg's early research, if these early practitioners and researchers are basically using the word association test for the detection of deception or each of these pioneers simply applied another previously existing interviewing procedure from Clinical Psychology. In the same light, though Leonarde Keeler is credited with creating the Searching Peak format, John Larson was practicing it in the field when Keeler was still a high school student. It appears far more likely Keeler merely adopted Larson's "Peak" procedure rather than create anything new. Likewise, what some today are calling separate and distinct Comparison Question techniques are in fact simple variations of the Comparison Question technique originated by John Reid in the late 1930's or early 1940's. Merely changing the number and test location of Relevant and Comparison Questions and calling it a different "technique" does not appear to have any significant effect on examination accuracy since they all seem to keep coming up with Reid's same validity and reliability rates of around 85\% (Nelson, 2011). For example, early versions of the "Utah Technique", for which peer review, published validity studies exist, originally included Backster's Symptomatic Question. These were, structurally, very different tests from the latest "Utah Technique", which now uses four Relevant Questions and three Comparison Questions and for which no validity studies exist. Yet, they are all called the "Utah Technique" (Horvath and Peters, 2013).

Although Reid originally referred to this new, third type of question as a Comparison Question, he and Inbau later adopted the term Control Question in deference to conventions of the time. This third type of question, today, is more correctly called a Comparison Question, not in deference to Reid's original term but due to changes in the psychological lexicon. Larson left Berkeley in 1923 to attend Rush Medical School in Chicago. While there, he worked part-time at the Illinois Institute for Juvenile Research conducting polygraph examinations at Joliet State Penitentiary. Larson appears to have consulted with Marston in the Frye case as Marston appears to have desired to parade Larson's field experience before the Court, along with their combined academic achievements. Larson, however, never officially participated in the testimony and indicated that this experience led him to conclude the polygraph was not ready for Court but would be acceptable for police work, essentially parroting the written Frye Appellate decision. Despite fundamental improvements in polygraph technique since 1922, 
notably the development of Reid's Comparison Question technique, instrumentation and accuracy research, this same mantra is still espoused by some law enforcement agencies in present times (ibid, Alder).

Leonarde Keeler, as noted previously, was first exposed to polygraph when Chief August Vollmer assigned him to assist John Larson in expanding upon Marston's Systolic Blood Pressure test. Though Keeler was only a high school student at the time, it appears he had a very charismatic personality and was somewhat of a polygraph kleptomaniac, obtaining credit for both instrumental and procedural innovations that were actually developed by others. During their long, strained association under Vollmer's formal and informal consul, Keeler was supposed to focus on improving the polygraph instrument while Larson was to devote his efforts to improving the procedures or technique and conducting research regarding examination validity and reliability (ibid, Bunn). To a certain extent, both performed in their assigned roles but, at least in the case of Leonarde Keeler, not in the manner Vollmer envisioned.

Although there is evidence that Keeler enrolled at the University of California at Berkeley, there doesn't appear to be any record that he actually attended classes. When Vollmer became Chief in Los Angeles, Keeler transferred to UCLA and, again, doesn't appear to have been much of a student in the year he was there. However, he did have occasion to work with Hiram Edwards, a physicist at the college and Charles Sloan, a reporter with the Los Angeles Times who also happened to be an accomplished machinist. The three were able to develop a new form of metal tambour that greatly improved the sensitivity of polygraph recordings. When Vollmer resumed his position as Chief of the Berkeley Police Department, Keeler, with the help of his father, also returned to the Bay Area and was accepted as a student in the Psychology Department at Stanford University in Palo Alto, California. He was mentored by Professor Walter Miles who had agreed to give Keeler some laboratory space and allowed Keeler to work on further refining the polygraph instrument. Again, now for the third school in a row, it appears unlikely that Keeler actually attended classes at Stanford. In 1927, while Miles and Keeler were on a sales trip to show Tyco Instruments Keeler's prototype polygraph, they stopped in Chicago where Keeler met Herman Adler, Director of the Illinois Institute of Juvenile Research, who offered Keeler a job on the spot as a polygraph examiner. Adler had previously traveled to Berkeley to see Larson's work, having been interested in Marston's early reports. In 1929, Keeler accepted Adler's offer and moved to Chicago (24, Alder). That same year, August Vollmer authored The Illinois Crime Survey, a rather scathing report about police corruption, particularly in Chicago (Wigmore, 1929). Vollmer moved to Chicago in 1930 to teach Police Science at the University of Chicago with the expectation that he might soon become Chief of the Chicago Police Department. As discussed previously, John Larson was already in 
Chicago attending Rush Medical School and conducting polygraph examinations for Adler at the Institute of Juvenile Research. The stage was therefore set with the three Californians, Vollmer, Larson and Keeler together again, this time in Chicago at the time of an event that forever changed the future of polygraph: the St. Valentine's Day Massacre. Before discussing the significance of this seminal event on polygraph, it is first useful to consider how social evolution, the media and presumably, the public in Chicago framed the issue of crime and criminal investigation.

\section{The Media and the "Lie Detector"}

As early as 1907, the New York Times reported Hugo Munsterberg's ability to Invent a Machine to Cure Liars" (New York Times, 1907) but it wasn't until 1909 that Charles Walk in The Yellow Circle used the term "lie detector" to describe Munsterberg's use of the chronoscope and work association test as "a machine that's a lie detector" (Walk, 1909). That same year, two Chicago newsmen, Edwin Balmer and William Harge created the fictional character Luther Trant who was described as a Scientific Detective using a three channel polygraph (pneumograph, galvanometer and glove plethysmograph) to unmask criminals (Balmer \& MacHarg, 1910). In 1910 Arthur Reeves created Craig Kennedy - The Truth Detector who used a two channel polygraph and Munsterberg's word association test to investigate crime (Reeve, 1912). Finally, in 1930 Chester Gould created the comic strip Dick Tracy and described the fictional detective using a Keeler Polygraph to catch criminals. It is interesting to note the Gould attend the month long Northwestern University Law School Scientific Crime Lab course on evidence collection and polygraph and, therefore, was very much aware of polygraph's "state of the art" at the time.

\section{Chicago in the 1920's}

In 1910 Henry Wigmore, Dean of the Northwestern University Law School established the first criminological research center, the American Institute for Criminal Law and Criminology. Dean Wigmore was later to be frequently referenced by fellow Law School Dean, Fred Inbau, for Wigmore's response to the 1922 Frye decision, "If there is ever devised a psychological test for the valuation of witnesses, the law will run to meet it" (Wigmore, 1940). At about the same time, Illinois established the first Juvenile Court based on the philosophy of Jane Adams' Chicago Hull House that crime was a disease that should be treated, i.e. correct, forgive and forget (Davis, 1973). This philosophy continues to periodically resurface and today can be seen in various Presi- 
dential Executive Orders (2015) restricting the FBI, DEA, ATFE and other federal law enforcement agencies' use of criminal records in conducting employment background checks, the EEOC's Revised Guidelines (2012) limiting the periods of accountability regarding credit and criminal records and the Ban-the-Box movement where various states and local governments prohibit public employers from soliciting information about criminal convictions until after job applicants have been given Conditional Offers of Employment (Slowik, 2015).

As a further outgrowth of the Juvenile Court, in 1909 the Institute for Juvenile Research was created in Chicago with William Healy as its first Director. Healy was a disciple of James and Munsterberg and repeated their notion that lying was a gateway to vice and polygraph should be used to cure lying (Healy, 1915). In 1916 Herman Adler became the second Director of the Institute. Adler had always been interested in lie detection and in fact had previously traveled to Berkeley to see John Larson's work with polygraph. Not surprisingly, in 1924 when Larson came to Chicago to attend Rush Medical School, Adler hired Larson at the Institute of conduct polygraph examinations. Although how this came to be is somewhat unclear, for some reason the Institute for Juvenile Research was also responsible for evaluating adult prisoners at Joliet State Penitentiary. Because of this responsibility, Larson began conducting between 100 and 150 polygraph examinations of inmates per month and advising the Parole Board regarding their suitability for parole. Ironically, present day Post - conviction Sex Offender Testing appears to have been long preceded by Larson's efforts in this area though no one has apparently reviewed his procedures or results.

By 1925 there had begun a protracted struggle between the American Institute for Criminal Law and Criminology at the Northwestern Law School and the Institute for Juvenile Research's work at the Joliet Penitentiary where the Nurture Progressives (Northwestern) believed crime would be reduced by improving environments and the Nature Progressives (Joliet) believed in segregation and sterilization, maintaining that criminal tendencies were the result of racial degeneracy and heredity (ibid, Alder).

On St. Valentine's Day, February 14, 1929, five individuals dressed in Chicago Police uniforms and believed to be working for the Capone gang, lined up five members of a rival Northside gang and two innocent bystanders in a garage and using tommy guns, killed all seven. While gang related murder was not unusual for Chicago in the 1920's, this event so outraged the Chicago Crime Commission that two members, Burt Massee, a Vice President with Colgate Palmolive, and Walter Olson, President of Olson Rug Company, agreed to fund the very first crime laboratory in the United States at Northwestern Law School with former Army Lt. Colonel Calvin Goddard as the Director. Goddard is credited with formalizing procedures for the emerging forensic science of ballistics and was instrumental in the New York Sacco and Vanzetti case. God- 
dard proceeded to examine all the tommy guns used by the Chicago Police as well as the surrounding suburban police departments and concluded that none were used in the St. Valentine's Day murders. Goddard's opinion was later verified when a weapon found in the possession of Fred "Killer" Burke, a member of the Detroit Purple gang known to affiliate with the Capone gang in Chicago, matched bullets recovered from the scene of the Chicago murders (myalcaponemuseum, 2015).

If ballistics was, therefore, the first forensic science, polygraph could well have been the second because in 1930, Leonarde Keeler was hired by this newly minted Northwestern University Scientific Criminal Detection Laboratory for the sole purpose of conducting polygraph examinations - free for law enforcement, flat fee per examination for the private sector. In addition to ballistics and polygraph, the Crime Lab soon added serology, hair and fiber analysis, plaster foot and tire mark identification, photography, Questioned Document analysis and an extensive library on the scientific investigation of crime. The Crime Lab also started with first school of forensics in 1931, a month long session where Keeler taught the first open polygraph course. Keeler's wife, Kay, was hired as an Assistant and was trained at the University of Chicago by Albert Osborn, becoming the first female Questioned Document examiner. Beginning in February of 1930, the Crime Lab, under the umbrella of the Northwestern Law School, began publishing the very first peer review professional journal devoted to law enforcement, the American Journal of Police Science with a polygraph article by Keeler in the first publication (Keeler L., 1930). Because of the Depression, it was largely revenues paid by private sector banks and retailers for Keeler's polygraph services that supported all the other forensic services and administration of the Crime Lab between 1930 and 1938. In 1938 the City of Chicago purchased the Crime Lab from the University for \$25,000 and it became, and is today, the Chicago Police Department Scientific Crime Laboratory (Inbau, 1985). Fred Inbau was appointed Director, Goddard returned to New York and Inbau assigned a young lawyer, John Reid, to look into the high error rate of specific issue polygraph examinations using the Relevant/Irrelevant questioning technique. Ironically, one of City's purchase stipulations was the Keeler would no longer be allowed to work at the Crime Lab, the basis for which has never been disclosed.

\section{Chicago After 1930}

While the use of forensics, including polygraph, to assist in criminal investigations was becoming established in Chicago, J. Edgar Hoover was admonishing Agent Melvin Purvis for using the services of the Northwestern Crime Lab to assist in the investigation of federal crimes. Hoover, however, was not above sending Agent Charles Appel in the 1930's to the month long training course at the Northwestern 
Crime Lab and subsequently copying the Lab's material to eventually start the FBI's own Crime Lab. Hoover, later sent at least one Agent to Leonarde Keeler, Inc. for several weeks of polygraph, specific training in the late 1930's. Unfortunately, polygraph did not seem to make the transition to the FBI's crime lab with the same level of professionalism as some of the other emerging forensic sciences. Early FBI polygraph examiners were either "preceptor" trained (read about polygraph procedures and/or watched other examiners conduct examinations) or were formerly trained somewhere else before joining the FBI. It was therefore fairly common in Chicago, particularly during the 1960's and 1970's for private polygraph examiners to be hired by banks to conduct internal theft investigations but receive the case facts (and give the test results) to the FBI Agent in charge of the case since both the number and quality of federal examiners at the time was insufficient for the need. This situation was rectified much later by upgrading the old Army polygraph school and including other, non-military federal agencies to eventually form the federal polygraph school presently operating as the National Academy of Credibility Assessment. While it was not widely known during the time of the Congressional Hearing leading to the 1981 Employee Polygraph Protection Act, most of the federal law enforcement agencies using polygraph were close to losing polygraph as an investigative tool until Congress essentially forced them to adopt many of the basic training protocols already in practice in the private sector (NSDD 84, 1983). Sadly, even today, the federal school still does not require the level of training John Reid was able to require in Illinois back in 1963 (ILCS 4301, 1963), particularly with regard to mandatory captive internships using licensed intern instructors and a minimum number of real, not simulated, case subjects. While Quality Assurance procedures sometimes catch mistakes that show up in question formulation and charts, numerous additional errors can only be identified by someone present at the time the intern conducts the examination, a reality recognized in medicine and other behavioral sciences.

In 1930, John Larson returned to Chicago and reprised his role polygraph testing inmates at Joliet State Penitentiary. As a very young, newly minted examiner, I had the experience of not only attending Joliet Warden Regan's retirement at this facility (1968) but, over the years, actually conducting polygraph examinations within the confines of the institution. I suspect Larson's experience dealing with actual criminals forever influenced his resolve to unequivocally reject polygraph findings based on laboratory studies using college students in artificial scenarios.

At the time, the Nature/Nurture argument, as interpreted in Chicago, had Larson (Southside/Institute of Juvenile Research) promoting a psycho - physiological source for crime and the Northwestern Crime Lab (Northside/Keeler/FBI) seeking a more proactive approach to criminal investigation. So, apparently at Vollmer's insistence, 
Larson and Keeler agreed to work together to resolve some basic issues: scientific accuracy at determining truth and deception vs. commercial effectiveness. This, of course, is exactly the same situation polygraph faces when confronted with the relative merits of specific issue accuracy vs. PCSOT and other unverifiable screening tests. In any case, Larson appears to be the first to attempt to standardize polygraph procedures and wrote, for Keeler, specific procedures on how to introduce the test (preamble), including the option to opt out of the test (voluntariness), to use a fixed RQ/IQ sequence, to use a fixed Blood Pressure settings (consistency), and an admonition to not use Keeler's "card trick" Acquaintance Test. Keeler was an amateur magician. With the intentions of stimulating untruthful subjects who thought they could "beat" the polygraph and calming the false positive fears of the truthful subjects, Keeler would have subjects pick from a marked deck of cards then test as to the identity of the card chosen. Since Keeler already knew which card was selected, he was always able identify the correct card and demonstrate the accuracy of the examination. While Keeler never stopped using his Card Test, it appears that he did in fact adopt a more standardized approach to polygraph procedures as indicated by his polygraph lectures both at the Northwestern Crime Lab and later at Leonarde Keeler, Inc.

Upon obtaining his medical degree, John Larson became responsible for conducting the psychiatric evaluations of all parolees in the Illinois State system. About this time Larson became convinced that his supervisor at the Institute of Juvenile Research, Herman Adler, was blocking Larson's attempts to expose corruption regarding the parole decisions. Larson left the Institute and proceeded to work at numerous mental health institutions from Detroit to Seattle, at one time teamed with the Indiana State Police to teach "clinical polygraph" and renamed the polygraph the "Reactograph", using the instrument to test lobotomy patients as part of mental disease diagnoses. Larson eventually became disillusioned with polygraph as a procedure for the detection of deception and became an outspoken critic of its use for anything other than mental health treatments. While John Larson most certainly did more than anyone since William Moulton Marston with regard to the scientific evaluation of polygraph accuracy and the standardization of polygraph procedures, Larson was very much opposed to artificial laboratory studies of polygraph which he called "using statistical analysis of artificial tests using undergraduates telling lies about meaningless games" (Alder, p. 121).

Although virtually unheard of today, in the early 1930's, Chicago medical doctor and psychologist, Orlando Scott, tried to get Keeler and the Northwestern Crime Lab to introduce polygraph in criminal proceedings. When this effort proved unsuccessful, he created his own National Detection of Deception Laboratory claiming to have 
a "100\% effective Thought Wave Detector" which he maintained that not even psychopaths could defeat since he could always "turn up the juice". Scott's device was actually a very large GSR instrument with a giant arrow - like needle bearing no resemblance to polygraph instruments of the time. Scott, however, was somewhat successful at getting his testimony based on this "lie detector" admitted in federal and state civil proceedings (Look, 1938).

While Leonarde Keeler may have taken credit for technical improvements in the polygraph instruments that others actually created and, apparently, did not develop either the Relevant/Irrelevant or Peak of Tension questioning techniques that he is sometimes associated with, he most certainly deserves to be credited for the commercialization of polygraph and its acceptance as an investigative tool by the police and federal government. Keeler promoted the idea of periodic screening tests by retailers and banks, a procedure nearly identical to PCSOT testing but focusing on integrity rather than sexual issues. Keeler was successful in getting such major employers as Marshall Fields, Walgreens and Zenith Radio to polygraph their employees and persuaded Lloyds of London to give Chicago banks a 10\% reduction on their insurance premiums when they had Keeler polygraph their employees every six months. While the police and government agencies did not have to pay the Northwestern Crime Lab for Keeler's polygraph services, commercial employers did and Keeler, in fact, is credited with supporting all the other forensic services at the Lab with the revenues obtained from private sector polygraph examinations after the Lab lost its private sector funding due to the Recession. Initial participants in the Northwestern month long forensics school who received polygraph instruction from Keeler included the Indianapolis, Kansas City, St. Louis, Cincinnati, Buffalo and Honolulu Police Departments as well as the State Police in Michigan, Indiana and North Dakota. After the Chicago Police acquired the Crime Lab from the University, Leonarde started Leonarde Keeler, Inc. and hired an old Berkeley associate, Charlie Wilson as a fellow examiner. Keeler then trained Charlie's wife, Jane, to become the first female polygraph examiner. In 1942, Keeler joined with T.P. Sullivan of the Illinois State Police to create the first Mobile Crime Lab with Keeler conducting field polygraph examinations. In 1944, Army CID used Keeler to polygraph German POW's incarcerated in the United States to determine which were sufficiently free of Nazi ideology to be repatriated as police officers in post-war Germany. In 1946, the Atomic Energy Commission used Keeler to create a periodic screening program at the Oak Ridge facility that Keeler's student, Russell Chatham later expanded into a program resulting in the testing of all 5,000 employees by teams of polygraph examiners (Keller, E., 1984). While this program was later disbanded, it was reinstated by the U.S. Department of Energy in 1999 to require periodic polygraph examinations of employee in the nuclear facilities under their jurisdiction (Alder, p.258). 
While Keeler, most certainly deserves credit for the commercialization of polygraph, the acquisition of the Scientific Crime Laboratory from Northwestern University with Prof. Fred Inbau as Director by the City of Chicago set the stage for the single person most responsible for the dedication, insight and originality that allowed polygraph to become by all measures a true science: John E. Reid.

\section{References}

Alder, K. (2007), The Lie Detectors: The History of an American Obsession, Free Press, New York, pp. 19-20.

Balmer, E. and MacHarg, W. (1910), The Achiements of Luther Trant, Small, Maynard \& Company, Boston.

Barta, M. (1992), Picturing Time: The Work of Etienne-Jules Marey, University of Chicago Press, Chicago.

Bunn, G. (2012), The Truth Machine - A Social History of the Lie Detector, Johns Hopkins University Press, Baltimore, p. 67.

Bunn, G. (1997), 'The Lie Detector, Wonder Woman and Liberty: The Life and Work of William Moulton Marston', History of the Human Sciences, vol. 10, no. 1, pp. 91-119.

Cannon, W. (1915), Bodily Changes in Pain, Hunger, Fear and Rage: An Account of Recent Researches into the Function of Emotional Excitement, Appleton, New York.

Davis, A. (1973), American Heroine: The Life and Legend of Jane Adams, Ivan R. Dee Publisher, Chicago.

Deakin, T. (1988), Police Professionalism: The Renaissance of American Law Enforcement, Charles Thomas, Springfield.

Detroit News, 1/23/48.

Frye v. U.S., 54 App. D.C. 46, 293 Fed. 1013, 12/3/1923.

Gross, H. (2014), Criminal Psychology: A Manual for Judges, Practitioners and Students, Gutenberg Ebook \#1320.

Healy, W. (1915), Honesty: A Study of the Causes and Treatment of Dishonesty Among Children, Bobbs-Merrill, Boston.

Horvath, F. and Peters, R. (2013), The Reid Polygraph Technique, American Polygraph Association Annual Seminar, Orlando, 9/12. 
Illinois Law Regarding the Licensing of Polygraph Examinations and Regulating the Practice of the Polygraph Technique, 224(ILCS 4301)8/23/63.

Inbau, F. (1985), Scientific Crime Detection: Early Efforts in Chicago, in August Vollmer: Pioneer in Police Professionalism, V2, Regional Oral History Office, Bancroft Library, University of California-Berkeley.

James, W. (1894), 'The Physical Basis of Emotion', Psychological Review, vol. 1, pp. 516529.

Jung, C. (1907), 'On Psychophysical Relations of the Associative Experiment', Journal of Abnormal Psychology, vol. 1, p. 247.

Keeler, E. (1984), The Lie Detector Man: The Career and Cases of Leonarde Keeler, Telshare Publishing, Boston.

Keeler, L. (1930), 'A Method For Detecting Deception', American Journal of Police Science, vol. 1, p. 48.

Los Angeles Times, 2/12/24.

Lombroso, C. (1876), L'uomo delinquente: alla medicima legale ed alle discipline carcerarie, Hoepli, Milan (Getty Research Institute Archieves).

Look, 1/4/1938, p. 29.

Marston, W. (1917), 'Systolic Blood Pressure Symptoms of Deception', Journal of Experimental Psychology, vol. 2, pp. 117-163.

Marston, W. and Pitkin, W. (1930), The Art of Sound Pictures, Appleton, New York.

Mechan, L. (1931), 'Frankenstein', Motion Picture Herald, 11/14.

Munsterberg, H. (1907), 'Nothing but the Truth', McClures Magazine, vol. 29, pp. 532-536.

Munsterberg, M. (1922), Hugo Munsterberg: His Life and Work, Appleton, New York, p. 149.

Myalcaponemuseum, www.myalcaponemueum.com/id186.htlm.

National Security Decision Directive 84 (1983); DoD Directives 5210.48, 5210.48R and 5210.78 (1986).

New York Times, 'Invents Machine for Cure of Liars', 9, 9/11/07. 
Nelson, R. (2011), 'Meta-analytical Survey of Criterion Accuracy of Validated Polygraph Techniques', Polygraph, vol. 40, no. 4.

Redstone, D. (1947), 'The Case of the Dormitory Thefts', Readers Digest, vol. 51, pp. 18-21, December.

Reeve, A. (1912), The Truth Detector, in The Treasure Train, Harper and Brothers, New York, 29.

Reid, J. and Inbau, F. (1977), Truth and Deception: The Polygraph ("Lie Detector") Technique, Williams and Wilkins Company, Baltimore.

Slowik, S. (2015), 'Compliance Update: Employment Practices and Procedures', APA Magazine, vol. 48, no. 1, pp. 51-56.

U.S. v. Frye, 130 S.Ct. 307, July, 1922.

Walk, C. (1909), The Yellow Circle, A.C.McClury, New York.

Wigmore, H. (ed.) (1929), Chapter Five: The Police (in Chicago), Illinois Crime Survey, Illinois Association for Criminal Justice, Chicago Crime Commission.

Wigmore, H. (1940), Treatise on Anglo-American System of Evidence, Little, Brown \& Company, Boston, 2, pp. 237-238. 